\title{
Quality Control Test for SFRC to be Used in Precast Segments
}

\author{
Climent Molins ${ }^{1}$, Antonio Aguado ${ }^{1}$, Antonio R. Marí ${ }^{1}$ \\ ${ }^{1}$ Dept. of Construction Engineering, Technical University of Catalonia, Jordi Girona 1-3, 08034 \\ BARCELONA (Spain)
}

\begin{abstract}
Current methods to measure tensile strength and toughness in Steel Fiber Reinforced Concrete (SFRC) show a considerable scatter. That scatter makes difficult the quality control, in particular when such properties are taken into account in the evaluation of overall strength of the precast tunnel lining segments, as in the case of the Line 9 of the subway in Barcelona. In order to improve the material assessment procedure, the Double Punch Test (DPT) has been recovered for the quality control of the tension behavior of SFRC. Results of an initial feasibility research are presented, showing a significant reduction of the scatter in the values of the tension strength and in the toughness. Other advantages shown by this test are: (1) the reduced size $150 \times 150 \mathrm{~mm}$ of the cylindrical specimens, compared with those used in beam test, and (2) the use of a conventional compression press controlled by displacement.
\end{abstract}

\section{INTRODUCTION}

The application of Steel Fiber Reinforced Concrete to structural members is nowadays experiencing a significant growth. Much research has been done to take into account the benefits of the inclusion of steel fibers in the capacity of structural members under shear and normal stresses. However, the implementation of SFRC on the actual construction works also requires a test to assess the quality of the material. It is specially needed to assess the tension behavior of SFRC. To that purpose, standards include the beam test: ASTM C1018, NBN B 15-238, RILEM TC 162TDF, and for SFR Shotcrete, the test is performed in panels: EFNARC and Round Determinate Panel (Bernard, 2001) (Table 1).

All these tests demand specific moulds to produce the specimens which are much heavier than those used for compression. In addition, the beam test always presents an uncomfortable scatter of its results when applied to normally low

Table 1. Specific failure surface in SFRC tension tests.

\begin{tabular}{|c|c|c|c|}
\hline TEST & CONFIGURATION & $\begin{array}{c}\text { FAILURE } \\
\text { SURFACE } \\
\left(\mathrm{cm}^{2}\right)\end{array}$ & $\begin{array}{l}\text { ESPECIFIC } \\
\text { FAILURE } \\
\text { SURFACE } \\
\end{array}$ \\
\hline $\begin{array}{c}\text { Beam } \\
\text { ASTM } \\
\text { C-1018 }\end{array}$ & $8 \quad \frac{1}{8}$ & $10 \times 10=100$ & 0,0286 \\
\hline $\begin{array}{c}\text { Beam } \\
\text { NBN } \\
\text { B } 15-238\end{array}$ & $\frac{1}{8}$ & $15 \times 15=225$ & 0,0133 \\
\hline $\begin{array}{c}\text { Beam } \\
\text { EFNARC }\end{array}$ & 1 & $\begin{array}{c}7,5 \times 12,5= \\
93,8\end{array}$ & 0,0182 \\
\hline $\begin{array}{l}\text { Beam } \\
\text { RILEM }\end{array}$ & $\frac{1}{8}$ & $\begin{array}{c}15 \times 12,5= \\
187,5\end{array}$ & 0,0152 \\
\hline $\begin{array}{c}\text { Panel } \\
\text { EFNARC }\end{array}$ & $\nabla$ & $\begin{array}{c}8 \times(32,5 \times 10) \\
=2.597,7\end{array}$ & 0,0722 \\
\hline $\begin{array}{l}\text { Round } \\
\text { Determinate } \\
\text { Panel }\end{array}$ & $\underset{\nabla}{\mid}$ & $\begin{array}{c}3 \times(40 \times 7,5)= \\
900\end{array}$ & 0,0238 \\
\hline DPT & & $\begin{array}{c}3 \times(7,5 \times 15)= \\
337,5\end{array}$ & 0,1274 \\
\hline
\end{tabular}


fiber contents. It is known that this scatter, in terms of tensile strength and toughness, is determined by the number of fibers actually bridging the crack. During the quality assessment of building works the scatter encountered in the results produced by the beam tests makes very difficult to define a threshold to take decisions.

Such problem has arisen during the construction of the precast tunnel lining segments of the L9 of the Barcelona's subway. This project is considered to be record-breaking with $12 \mathrm{~m}$ diameter TBMexcavated tunnel of about $40 \mathrm{~km}$ length. Reinforced concrete rings of Section 4 of the line content, according to the design, 25 or $30 \mathrm{~kg} / \mathrm{m} 3$ of steel fibers plus $60 \mathrm{~kg} / \mathrm{m} 3$ of conventional reinforcement.

In order to improve material assessment procedure, the Double Punch Test (DPT), that was developed thirty years ago, has been recovered for the quality control of the tension behavior of SFRC. In a first attempt to appraise its capability, twenty samples were tested using Double punch test. The results showed: (1) a significant reduction of the scatter in terms of the tension strength and in those of toughness, (2) sharp dependence on the fiber contents of the concrete. Other advantages that show DPT are: (1) the cylindrical specimens are of reduced size 150x150 mm and (2) a conventional compression press controlled by displacement can be used.

In this paper, the description of the test, its advantages in the case of SFRC and the results of a preliminary campaign with its analysis and discussion are presented.

\section{DOUBLE PUNCH TEST PROCEDURE}

Barcelona test for fiber reinforced concrete (FRC) is the adaptation of the DPT, used to determinate the tensile strength of plain concrete. DPT was developed in the 1970's as an alternative to the widely spread Brazilian one, that allows to indirectly measure the tensile strength of concrete. Since Chen (1970) presented DPT, notable research effort has been devoted to it. However, it did not become a standard as the Brazilian indirect tension test, probably because the latter was already well established and easier to perform.

In this test, a concrete cylinder is placed vertically in a uniaxial compression press with two steel circular punches centered, that transmits the compression force, at the top and bottom surfaces of the cylinder (Figure 1).

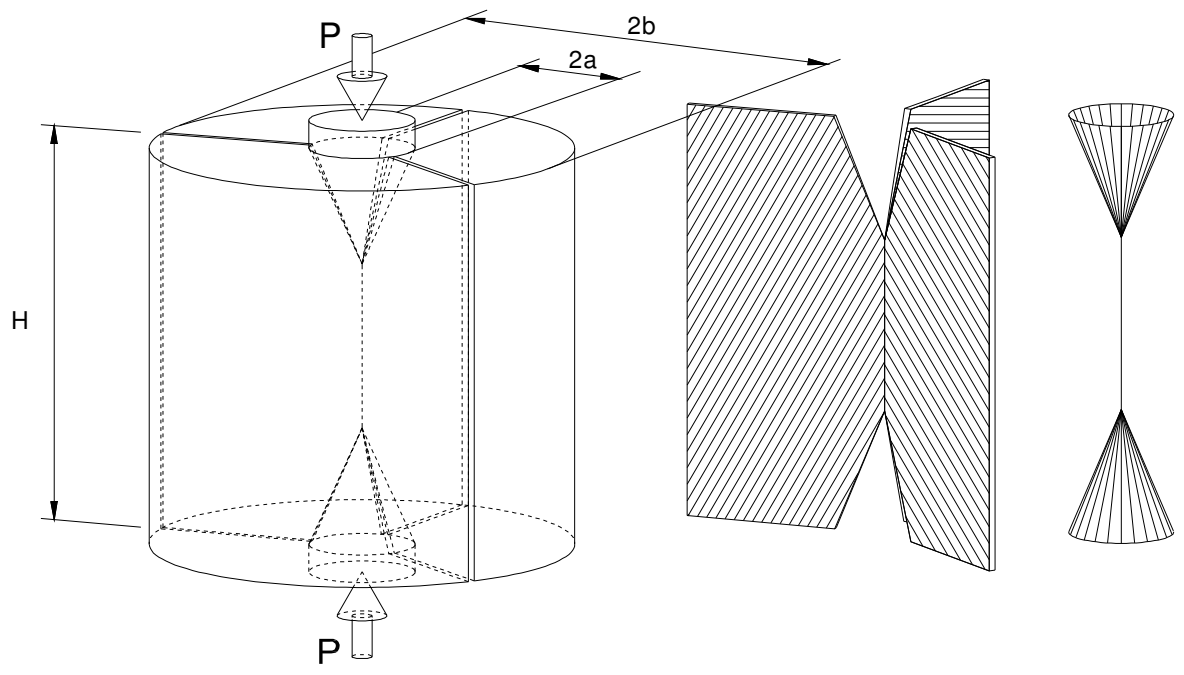

(a) Double-punch test arrangement

(b) Failure surfaces

Figure 1. Double-punch test arrangement, mechanism of failure and failure surfaces.

Several approaches have been developed to evaluate the indirect tensile strength from the doublepunch test. Chen (1970) derived an expression applying the limit analysis of perfectly plastic material: 


$$
f_{t}=\frac{P}{\pi\left(1.2 b H-a^{2}\right)}
$$

where $P$ is the applied load at failure, $H$ the height of the specimen, $b$ is the radius of the cylinder and $a$ is the radius of the punch.

Chen and Yuan (1980) proposed another approach, which reduces the value of expression (1) by $25 \%$, by applying the Finite Element Method assuming that the concrete of the cylinder is a linear elastic, plastic strain-hardening and fracture material:

$$
f_{t}=\frac{0.75 P}{\pi\left(1.2 b H-a^{2}\right)}
$$

Bortolotti (1988) derived also an approach assuming a modified Coulomb failure criterion for concrete and compared its results with those obtained in the experiments published by Chen:

$$
f_{t}=\frac{P}{\pi\left(b H-a^{2} \cot \alpha\right)}
$$

where $\alpha$ is derived from the internal friction angle of concrete.

Marti (1989) derived an expression applying the Bazant's non-linear fracture mechanic approach:

$$
f_{t}=0.4 \frac{P}{4 b^{2}} \sqrt{1+\frac{2 b}{\lambda d_{a}}}
$$

where $\lambda$ is a constant which depends on the material (varying from 37 to 68 for concrete) and $d_{a}$ is the maximum aggregate size. In deriving expression (4), it was supposed that $b / h$ was equal to 1 , as recommended by Chen. These expressions are derived from equilibrium equations in terms of displacements' functions and applying the virtual work principle in the kinematics of the failure drawn in Figure 1, that shows the scheme of the test and its typical failure.

Recently, Wei and Chau (2000a, 2000b) derived an approach for stress analysis within a finite isotropic elastic solid cylinder under the double punch test. The paper (Wei and Chau, 2000b) presented the influence of the geometric ratios and the Poisson's modulus. The tensile strength yield by their approach agrees with those achieved analytically and experimentally by Chen and with those obtained by the Bortolotti's expression (3) by $a / b>0.25$.

\section{EXPERIMENTAL CAMPAIGN}

The aforementioned research appraises the feasibility of the double-punch test in determining the tensile strength of plain concrete. However, almost no research has been devoted to its extension to SFRC. Probably, that is due to the different degree of use and development between both, plain concrete and SFRC.

A research group in the Department of Construction Engineering at the Technical University of Catalonia was commissioned, by the public company responsible of the design and constructions of the new L9 of the subway in Barcelona, to look for topics of research that could improve the construction of such a line. In that frame, it was proposed to use derive a test, named Barcelona, as an alternative to the four point beam bending test. 
The experimental research was designed to analyze the effect of varying some significant parameters. Table 2 shows the selected parameters and Table 3 summarizes the tests carried out, distinguishing between the origin of the concrete: from the plant of precast segments at Can Zam or from the plant at Gorg, which present different strength and different volume of fibers and type of fibers. Can Zam SFRC presents a compression strength of $50 \mathrm{~N} / \mathrm{mm}^{2}$ and contents $30 \mathrm{~kg} / \mathrm{m}^{3}$ of fibers $50 \mathrm{~mm}$ long with a diameter of $1 \mathrm{~mm}$ (aspect ratio of 50). Gorg SFRC presents a compression strength of $40 \mathrm{~N} / \mathrm{mm}^{2}$ and contents $25 \mathrm{~kg} / \mathrm{m}^{3}$ of fibers $50 \mathrm{~mm}$ long with a diameter of $0.75 \mathrm{~mm}$ (aspect ratio of 66.7). In addition, the specimens $150 \mathrm{~mm}$ height correspond to a half of a $300 \mathrm{~m}$ height sample. A set of twenty cylindrical $300 \mathrm{~mm}$ height specimens were required to perform the experimental program.

Table 2: Test variables.

\begin{tabular}{|c|c|c|}
\hline Variable & Values & Observations \\
\hline \multirow{2}{*}{ Punch diameter } & $38 \mathrm{~mm}$ & $\emptyset_{\text {specimen }}=3 \cdot \emptyset_{\text {punch }}$ \\
\hline & $50 \mathrm{~mm}$ & $\emptyset_{\text {specimen }}=4 \cdot \varnothing_{\text {punch }}$ \\
\hline \multirow{2}{*}{$\begin{array}{l}\text { Slenderness of } \\
\text { the specimen }\end{array}$} & $2(300 \mathrm{~mm}$ height $)$ & \multirow[b]{2}{*}{$\begin{array}{l}\text { Two specimens obtained } \\
\text { from cutting one of } 300 \mathrm{~mm}\end{array}$} \\
\hline & 1 (150 mm height) & \\
\hline \multirow{3}{*}{ Loading speed } & $0,75 \mathrm{~mm} / \mathrm{min}$ & \multirow{3}{*}{$\begin{array}{l}\text { Height speed } \\
\text { Medium speed } \\
\text { Low speed }\end{array}$} \\
\hline & $0,5 \mathrm{~mm} / \mathrm{min}$. & \\
\hline & $0,25 \mathrm{~mm} / \mathrm{min}$ & \\
\hline \multirow[t]{2}{*}{$\begin{array}{l}\text { Eccentricity of } \\
\text { the load } \\
\text { (punches) }\end{array}$} & $\begin{array}{l}\text { No eccentricity } \\
\text { One punch } 5 \mathrm{~mm} \text { eccentric and the other one } \\
\text { centered (1ecc.) }\end{array}$ & \multirow[t]{2}{*}{$\begin{array}{l}\text { Tested on } 150 \mathrm{~mm} \text { height } \\
\text { specimen }\end{array}$} \\
\hline & $5 \mathrm{~mm}$ eccentric both punches (2ecc.) & \\
\hline \multirow{2}{*}{$\begin{array}{l}\text { Position of the } \\
\text { molded face of } \\
\text { the specimen }\end{array}$} & $\begin{array}{l}\text { Molded face (bottom half) or cut face (upper } \\
\text { half) on the lower punch (pos.1) }\end{array}$ & \multirow{2}{*}{$\begin{array}{l}\text { Tested on } 150 \mathrm{~mm} \text { height } \\
\text { specimen }\end{array}$} \\
\hline & $\begin{array}{l}\text { Cut face (bottom half) o finished face (upper } \\
\text { half) on the lower punch (pos.2) }\end{array}$ & \\
\hline
\end{tabular}

Table 3 shows the adopted combinations of values of the selected variables that were been tested. As summarized in Table 2, three different options were simulated in relation with the eccentricity to appraise the sensitivity of the test to errors in the placement of the specimen on the press. The radiuses of the punch were selected in the range recommended by previous experiences.

\section{ANALYSIS OF TEST RESULTS}

Table 4 shows the results achieved in the tested set of specimens. Failure loads of the pairs of $150 \mathrm{~mm}$ height specimens, obtained by cutting a $300 \mathrm{~mm}$ one, are in most of cases almost identical. $300 \mathrm{~mm}$ height specimens present a failure load of about $25 \%$ to $35 \%$ larger than those of $150 \mathrm{~mm}$. Also in those higher samples, radial cracks didn't achieve the total height as normally occurred in $150 \mathrm{~mm}$ height samples (Figure 2). This fact implies a different behavior at failure.

Results were not sensitive to the position of the molded or cut face during the test. Testing speed didn't significantly affect failure loads. Only some increase is noticed in Can Zam samples. It was also verified that normal working eccentricities have no noticeable effect.

The scatter (12\%) that shows the experiments in terms of failure loads is significantly lower than those obtained in beam tests with similar fiber contents which actually are about $20 \%$ to $25 \%$. 
Table 3. List of tests.

\begin{tabular}{llccccc}
\hline$\varnothing$ punch & $\begin{array}{c}\text { H } \\
\text { specimen }\end{array}$ & $\begin{array}{c}\text { Speed } \\
\mathrm{mm} / \mathrm{min}\end{array}$ & Eccentric. & Position & \multicolumn{2}{c}{ Number of specimen } \\
Zam & Gorg \\
\hline $50 \mathrm{~mm}$ & $300 \mathrm{~mm}$ & 0,50 & No & & $1+9$ & $7+9$ \\
$38 \mathrm{~mm}$ & $300 \mathrm{~mm}$ & 0,50 & No & & $7+8$ & $1+8$ \\
$38 \mathrm{~mm}$ & $150 \mathrm{~mm}$ & 0,50 & No & 1 & $10 \mathrm{u}+\mathrm{b}$ & $10 \mathrm{u}+\mathrm{b}$ \\
$38 \mathrm{~mm}$ & $150 \mathrm{~mm}$ & 0,75 & No & 1 & $3 \mathrm{u}+\mathrm{b}$ & $6 \mathrm{u}+\mathrm{b}$ \\
$38 \mathrm{~mm}$ & $150 \mathrm{~mm}$ & 0,25 & No & 1 & $4 \mathrm{u}+\mathrm{b}$ & $2 \mathrm{u}+\mathrm{b}$ \\
$38 \mathrm{~mm}$ & $150 \mathrm{~mm}$ & 0,50 & 1 ecc. & 1 & $5 \mathrm{u}+\mathrm{b}$ & $3 \mathrm{u}+\mathrm{b}$ \\
$38 \mathrm{~mm}$ & $150 \mathrm{~mm}$ & 0,50 & 2 ecc. & 1 & $2 \mathrm{u}+\mathrm{b}$ & $4 \mathrm{u}+\mathrm{b}$ \\
$38 \mathrm{~mm}$ & $150 \mathrm{~mm}$ & 0,50 & No & 2 & $6 \mathrm{u}+\mathrm{b}$ & $5 \mathrm{u}+\mathrm{b}$ \\
\hline
\end{tabular}

Note: $u$ and $b$ are used to mean upper half and bottom half.

Table 4. Failure loads, energy and number of radial cracks.

\begin{tabular}{|c|c|c|c|c|c|c|c|c|c|}
\hline Origin & $\begin{array}{c}\text { Øpunch } \\
\text { (mm) }\end{array}$ & $\begin{array}{c}\mathrm{N}^{\mathrm{o}} \\
\text { spec }\end{array}$ & $\begin{array}{c}\text { Height } \\
(\mathrm{mm})\end{array}$ & $\begin{array}{l}\text { Test. speed } \\
\mathrm{mm} / \mathrm{min}\end{array}$ & $\begin{array}{c}\text { Eccent. } \\
(\mathrm{mm})\end{array}$ & Pos. & $\begin{array}{c}\mathrm{P} \\
(\mathrm{kN})\end{array}$ & $\begin{array}{c}\text { Energy } \\
(\mathrm{J})\end{array}$ & $\begin{array}{l}\text { Radial } \\
\text { cracks }\end{array}$ \\
\hline \multirow{16}{*}{$\begin{array}{l}\text { Can } \\
\text { Zam }\end{array}$} & \multirow[t]{2}{*}{50} & 1 & 300 & 0,50 & 0 & 1 & 314 & 364 & 4 \\
\hline & & 9 & “ & “ & “ & 1 & 328 & 351 & 3 \\
\hline & \multirow[t]{14}{*}{38} & 7 & " & "“ & " & 1 & 222 & 460 & 3 \\
\hline & & 8 & “ & “ & “ & 1 & 232 & 394 & 3 \\
\hline & & \multirow[t]{2}{*}{10} & $150 \mathrm{~b}$ & “ & “ & 1 & 186 & 174 & 3 \\
\hline & & & $150 \mathrm{u}$ & “ & “ & 1 & 193 & 205 & 3 \\
\hline & & \multirow[t]{2}{*}{3} & $150 \mathrm{~b}$ & 0,75 & “ & 1 & 207 & 178 & 3 \\
\hline & & & $150 \mathrm{u}$ & “ & & 1 & 208 & 226 & 2 \\
\hline & & \multirow[t]{2}{*}{4} & $150 \mathrm{~b}$ & 0,25 & “ & 1 & 177 & 206 & 3 \\
\hline & & & $150 \mathrm{u}$ & “ & “ & 1 & 170 & 194 & 3 \\
\hline & & \multirow[t]{2}{*}{5} & $150 \mathrm{~b}$ & 0,50 & 1 p 5 & 1 & 188 & 232 & 2 \\
\hline & & & $150 \mathrm{u}$ & “ & “ & 1 & 188 & 302 & 3 \\
\hline & & \multirow[t]{2}{*}{2} & $150 \mathrm{~b}$ & 0,50 & 2 p 5 & 1 & 179 & 207 & 3 \\
\hline & & & $150 \mathrm{u}$ & “ & & 1 & 200 & 266 & 4 \\
\hline & & \multirow[t]{2}{*}{6} & $150 \mathrm{~b}$ & 0,50 & 0 & 2 & 191 & 285 & 4 \\
\hline & & & $150 \mathrm{u}$ & “ & “ & 2 & 188 & 245 & 3 \\
\hline \multirow{16}{*}{ Gorg } & \multirow[t]{2}{*}{50} & 7 & 300 & “" & “" & 1 & 285 & 325 & 3 \\
\hline & & 9 & “ & “ & “ & 1 & $190 *$ & $549^{*}$ & $4^{*}$ \\
\hline & \multirow[t]{14}{*}{38} & 1 & “ & “ & “ & 1 & 220 & 235 & 2 \\
\hline & & 8 & “ & “ & “ & 1 & 231 & 202 & 2 \\
\hline & & \multirow[t]{2}{*}{10} & $150 \mathrm{~b}$ & “ & “ & 1 & 175 & 219 & 4 \\
\hline & & & $150 \mathrm{u}$ & “ & “ & 1 & 184 & 188 & 3 \\
\hline & & \multirow[t]{2}{*}{6} & $150 \mathrm{~b}$ & 0,75 & “ & 1 & 168 & 90 & 2 \\
\hline & & & $150 \mathrm{u}$ & “ & “ & 1 & 166 & 150 & 2 \\
\hline & & \multirow[t]{2}{*}{2} & $150 \mathrm{~b}$ & 0,25 & “ & 1 & 168 & 128 & 2 \\
\hline & & & $150 \mathrm{u}$ & “ & “ & 1 & 133 & 108 & 2 \\
\hline & & \multirow[t]{2}{*}{3} & $150 \mathrm{~b}$ & 0,50 & 1 p 5 & 1 & 176 & 163 & 3 \\
\hline & & & $150 \mathrm{u}$ & “" & “ & 1 & 176 & 163 & 4 \\
\hline & & \multirow[t]{2}{*}{4} & $150 \mathrm{~b}$ & 0,50 & 2 p 5 & 1 & 168 & 103 & 3 \\
\hline & & & $150 \mathrm{u}$ & “" & & 1 & 163 & 175 & 3 \\
\hline & & \multirow[t]{2}{*}{5} & $150 \mathrm{~b}$ & 0,50 & 0 & 2 & 156 & 128 & 2 \\
\hline & & & $150 \mathrm{u}$ & “ & “ & 2 & 152 & 112 & 2 \\
\hline
\end{tabular}

Note: $\mathrm{u}$ and $\mathrm{b}$ are used to mean upper half and bottom half. 


\section{CONCLUSIONS}

The use of the DPT is proposed for the quality control of SFRC in precast tunnel lining segments. The experiments show a reduced scatter in terms of failure load and energy, of about $12 \%$.

The parametric analysis showed that testing velocities of 0.25 to $0.50 \mathrm{~mm} / \mathrm{min}$ are appropriate and the $\Phi 38 \mathrm{~mm}$ punches (one fourth of the specimen's diameter) present lower scatter. Because of that, $0.50 \mathrm{~mm} / \mathrm{min}$ testing velocity and $38 \mathrm{~mm}$ punches have been selected to perform the test. In addition, normal working errors (eccentric placing of the punches) presented no noticeable effect in the results. Also, inverting the position of the

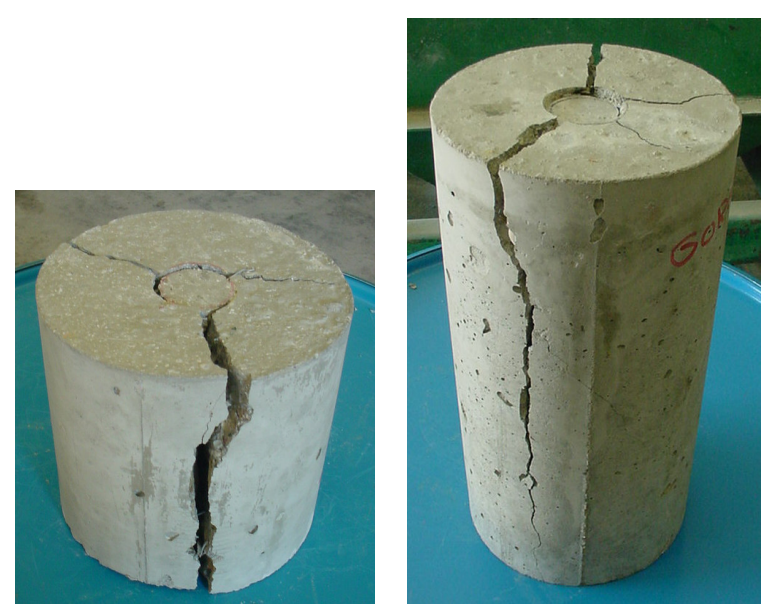

Figure 2. Tested 150 and $300 \mathrm{~mm}$ height samples. molded face vertically didn't affect the results. More consistent results were achieved using $150 \mathrm{~mm}$ height specimens.

These encouraging results deserve a further research effort to achieve a better understanding of the mechanics involved in the double punch test and to standardize it as a quality assessment tool for the tension properties of SFRC: tensile strength and toughness.

\section{ACKNOWLEDGMENTS}

The authors thank Gestió d'Infraestructures, S.A. (GISA), the public company responsible of the design and construction of the L9 of the Barcelona's subway, for funding this research developed at the Department of Construction Engineering of UPC (Technical University of Catalonia), and all those people who have been involved in it, in particular Mr. Sergi Saludes.

\section{REFERENCES}

Bernard, E.S., 2001. "The Influence of thickness on performance of Fiber-Reinforced Concrete in a Round determinate Panel test". Cement, Concrete and Aggregates, 23 (1), pp 27-33.

Bortolotti, L., 1988. "Double Punch Test for Tensile and Compressive Strengths in Concrete", ACI Materials Journal, 85-M4, pp. 26-32.

Chau, K.T. and Wei, X.X., 2000a. "Finite solid circular cylinders subjected to arbitrary surface load : Part I. Analytic Solution.” International Journal of Solids and Structures, 37 (40), pp. 5707-5732.

Chau, K.T. and Wei, X.X., 2000b. "Finite solid circular cylinders subjected to arbitrary surface load : Part II. Application to double punch test." International Journal of Solids and Structures, 37 (40), pp. 5733-5744.

Chen, W.F., 1970. "Double punch test for tensile strength of concrete", ACI Materials Journal. 67 (2), pp. 993-995.

Chen, A.C.T. and Chen, W.F., 1975. "Constitutive equations and punch-indentation", Journal of the Engineering Mechanics Division ASCE, 101 (6), pp. 889-905.

Chen, W.F. and Yuan, R., 1980. "Tensile Strength of Concrete: Double Punch Test". Journal of Structural Division ASCE, 106 (8), pp. 1673-1693.

Institut Belge de Normalisation, 1992. "NBN B 15-238 Essais des bétons renforcés de fibers - Essai de flexion sur éprouvettes prismatiques. Bruxelles.

Marti, P., 1989. "Size effect in Double Punch tests on Concrete cylinders", ACI Materials Journal, 86M58, pp. 597-601. 